\title{
The Dictionary of Lexicography and Dictionary Research
}

Rufus H. Gouws, Department of Afrikaans and Dutch, Stellenbosch University, Stellenbosch, Republic of South Africa (rhg@sun.ac.za) and

Herbert Ernst Wiegand, Germanistisches Seminar, Universität Heidelberg, Heidelberg, Germany (herbert.ernst.wiegand@gs.uni-heidelberg.de)

\begin{abstract}
This article presents a brief explanation of the current state of the work on the Wörterbuch zur Lexikographie und Wörterbuchforschung. It is done in a way that gives a general impression of the structure of this multivolume specialised dictionary.
\end{abstract}

Keywords: ALPHABETICAL EQUIVALENT INDEX, FUNCTIONAL CROSS-REFERENCE ARTICLE STRETCH, SPECIALISED DICTIONARY

Opsomming: Hierdie artikel bied 'n kort uiteensetting van die huidige stand van die werk aan die Wörterbuch zur Lexikographie und Wörterbuchforschung. Dit het ten doel om 'n algemene indruk te gee van die struktuur van hierdie meerdelige vakwoordeboek.

Sleutelwoorde: ALFABETIESE EKWIVALENTREGISTER, FUNKSIONELE KRUISVERWYSINGSARTIKELTRAJEK, VAKWOORDEBOEK

The full bilingual title of this specialised dictionary is: Wörterbuch zur Lexikographie und Wörterbuchforschung/Dictionary of Lexicography and Dictionary Research. Mit englischen Übersetzungen der Umtexte und Definitionen sowie Äquivalenten in neun Sprachen/With English translations of the outer texts and definitions as well as equivalents in nine languages.

This dictionary is edited and compiled by Michael Beißwenger (Dortmund), Rufus H. Gouws (Stellenbosch), Matthias Kammerer (Karlsruhe), Angelika Storrer (Dortmund), Herbert Ernst Wiegand (Heidelberg) and Werner Wolski (Paderborn). Including the lemma signs given in German, this is a dictionary that presents equivalents in ten languages. The following collaborators are responsible for translating the German lemma signs and finding appropriate translation equivalents:

- Afrikaans: Rufus H. Gouws (Stellenbosch)

- Bulgarian: Pavel Petkov (Sofia)

- English: Rufus H. Gouws

- French: Franz Josef Hausmann (Erlangen)

- Italian: Laura Giacomini/Giovanni Rovere (Heidelberg)

- Portuguese: Stefan J. Schierholz (Erlangen)/Rute Costa (Lissabon) 
- Russian: Ekaterina Butina-Koller (München)

- Spanish: Teresa Fuentes Morán (Salamanca)

- Hungarian: Regina Hessky/Zita Hollós (Budapest)

All the outer texts of the dictionary are given in both German and English. Maria Smit (Stellenbosch) and Rufus H. Gouws are responsible for the English translations of these texts. The dictionary will contain more or less 13000 lemmata, which includes more or less 7400 cross-reference lemmata. The relative high number of cross-reference lemmata is due to the fact that all multiword terms are presented in a non-natural order, resulting in functional cross-reference article stretches like the following:

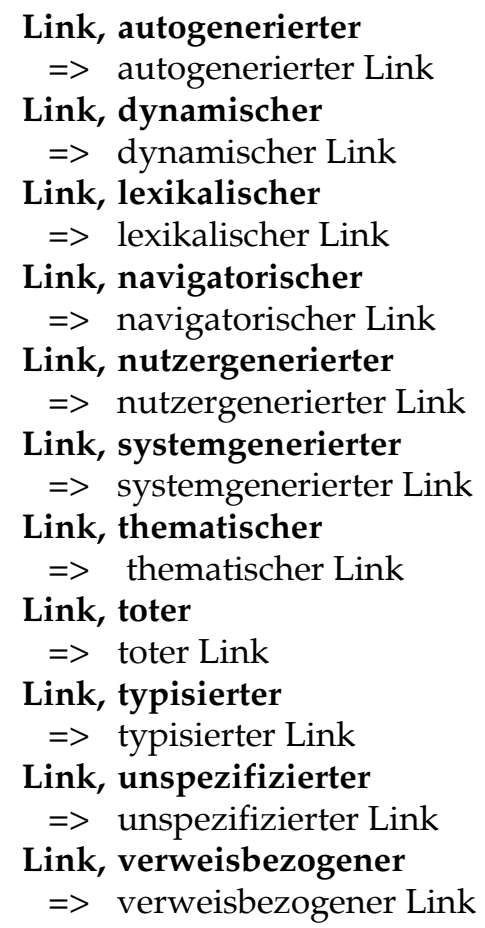

The genuine function of a functional cross-reference article stretch consists therein that the user can recognise which and how many multiword terms of the same type, e.g. ADJECTIVE NOUN, can combine with the same noun (here link) to be presented as lemmata in this dictionary.

The dictionary will be published in four volumes by the publishing house Walter de Gruyter. The contents of the different volumes are as follows:

Volume 1: Front matter texts, article stretches A-C

Volume 2: D-K

Volume 3: L-Z, back matter texts

Volume 4: Index volume: nine alphabetical equivalent access indexes. 
A brief description of the project with a demo-version of the dictionary articles can be found at http://www.fabulex.de. A more comprehensive presentation can be found at http://woerterbuch-portal.de as well as in the references cited below.

The current state of the project (July 2009) is as follows:

(a) Volume 1 contains the following front matter texts, in both German and English:

- Two-toned graphical presentation of the consultation possibilities in the dictionary, given on the front inside cover (with the English version on the back inside cover)

- Preface by the editors

- Preface by the collaborators regarding the terminological equivalence

- Guidelines for the user

- Systematic introduction

- Alphabetical access index for the Systematische Einführung

- Alphabetical list A-Z of lemma signs from other subject fields

The German and English versions of these front matter texts have been completed, with some still in the final phase of editing. The article stretches A-C have been completed and Volume 1 is due in the fourth term of 2009.

(b) Volume 2 contains the article stretches D-K. The dictionary articles of the article stretches $\mathrm{D}$ and $\mathrm{E}$ have been written and are already on the web. A part of the article stretches $\mathrm{F}-\mathrm{K}$ have been completed and are on the web in a password-protected environment. The accompanying equivalents are being prepared in a separate equivalent table from where they are automatically integrated into the dictionary articles.

(c) Volume 3 contains the article stretches L-Z and supplements A-Z. Many of these articles have already been written. This volume also contains the following back matter texts regarding the dictionary basis:

- the alphabetical list regarding Category I: Dictionaries and dictionary supplements

- the alphabetical list regarding Category II: Metalexicographic and other literature

The examples in the dictionary articles come from the references given in Category I. References in Category II are indicated in the reference position of the dictionary articles. The terms that receive a lexicographic treatment in the dictionary are employed in these references.

(d) CD-ROMs. Volumes 1 and 2 have an accompanying CD-ROM. The CD$\mathrm{ROM}$ in the first volume contains the volume-specific parts of the alpha- 
betical lists of Category I and Category II as well as the nine partial equivalent indexes for the article stretches A-C. The CD-ROM in the second volume contains the respective partial lists and equivalent indexes of volumes 1 and 2. By means of the CD-ROMs, one can firstly find the references given in volumes 1 and 2 prior to the publication of the third volume and, secondly, the articles can be accessed via the partial equivalent indexes.

(e) The fourth volume is an index volume, compiled by Matthias Kammerer. It contains nine alphabetical equivalent access indexes and is due shortly after the publication of the third volume.

The Wörterbuch zur Lexikographie und Wörterbuchforschung is a specialised learning and consultation dictionary for experts and semi-experts. Consequently it can be used effectively in situations of impeded specialised text reception with specific search questions regarding individual terms. It furthermore has a mediostructural arrangement that has been devised to ensure successful systematic dictionary-internal terminological consultation.

\section{Further information}

Kammerer, Matthias. 2001 [2002]. XML-getaggte Wörterbuchartikel. Ein Bericht aus der Praxis des Wörterbuchs zur Lexikographie und Wörterbuchforschung. Lexicographica 17: 249-301.

Wiegand, Herbert Ernst. 2003. Wörterbuch zur Lexikographie und Wörterbuchforschung/ Dictionary of Lexicography and Dictionary Research. Städtler, Thomas (Ed.). 2003. Wissenschaftliche Lexikographie im deutschsprachigen Raum. Im Auftrag der Heidelberg Akademie der Wissenschaften: 417-437. Heidelberg: Winter Verlag.

Wiegand, Herbert Ernst. 2003a. Wörterbuch zur Lexikographie und Wörterbuchforschung (WLWF). Dictionary of Lexicography and Dictionary Research. Eine kurze Projektbeschreibung. Botha, Willem (Ed.). 2003. 'n Man wat beur. Huldigingsbundel vir Dirk van Schalkwyk: 368-384. Stellenbosch: Bureau of the WAT.

Wiegand, Herbert Ernst. 2004. Über die Unterschiede von Fachlexikographie und Terminographie. Am Beispiel des Wörterbuchs zur Lexikographie und Wörterbuchforschung. Wiegand, Herbert Ernst (Ed.). 2004. Studien zur zweisprachigen Lexikographie mit Deutsch IX: 135-152. Germanistische Linguistik 178. Hildesheim/Zürich/New York: Georg Olms.

Wiegand, Herbert Ernst. 2004a. Überlegungen zur Mediostruktur in Fachwörterbüchern. Auch am Beispiel des Wörterbuchs zur Lexikographie und Wörterbuchforschung. Brdar-Szabó, Rita and Elisabeth Knipf-Komlósi (Eds.). 2004. Lexikalische Semantik, Phraseologie und Lexikographie. Abgründe und Brücken. Festgabe für Regina Hessky: 339-365. Duisburger Arbeiten zur Sprachund Kulturwissenschaft 57. Frankfurt a.M.: Peter Lang.

Wiegand, Herbert Ernst. 2004b. Reflections on the Mediostructure in Special-Field Dictionaries. Also According to the Example of the Dictionary of Lexicography and Dictionary Research. Lexikos 14: 195-221.

Wiegand, Herbert Ernst. 2007. Zum Stand der Arbeiten am Wörterbuch zur Lexikographie und Wörterbuchforschung. Zeitschrift für germanistische Linguistik 35: 182-184. 